症例

乳児期よりうっ血性心不全を呈した心房中隔欠損症の 1 治験例

\author{
函館五稜郭病院心葴血管外科, 外科*, 小児科“* \\ 及川佑一郎村井英夫* 安田一平** \\ 岩手医科大学麻酔科 \\ 川村隆 枝
}

乳児期より5っ血性心不全をくり返し，早期外科治療にて症状の改善を得た心房中隔 欠損症の 1 症例を経験した。症例は 1 葴 8 力月女児. 10 力月時に重症心不全にて入院, 内科治療を行った．12力月の心精查にて肺動脈圧36/10 (22) $\mathrm{mmHg}$, 肺体血流量比 2.5, 左右短絡 $66 \%$ のSD と判明. 心不全症状の改善, 肺高血压を合併していないことより経 過観察の方針とした。 1 歳 7 カ月, 再び心不全にて入院. 内科治療を行ったがその反応 は十分でなく，再検した心䁍カテーテル検查にて肺動脈王46/10(24) $\mathrm{mmHg}$ と前回より 上昇を認めたので 1 歳 8 カ月にて根治手術を行った。手術は単純超低体温法にて $25 \times 15$ mm の中心部欠損の ASD を直接释合した。術後程過は良好で臨床症状の改善も著明で あった。

柬引用語：心房中隔欠損症, 乳児期心不全, 早期外科治療

はじめに

心房中隔欠損症 (以下 ASD) は, 先天性心疾患の5 ちであ発生頻度の高い疾患の 1 つであるか，乳幼児期 および小児期の臨床経過は良好な疾患とされてい ॐ1).

ASD にらっ血性心不全(以下 CHF)を併発するのは 比較的高龄者になってからであり，乳児期にCHFを 呈するのは稀である2331.

私達は生後10カ月より CHFをくり返し1歳 8 カ月 にて外科治療を行い良好な結果を得た 1 例を経験した ので報告する。

$$
\text { 症例 }
$$

患者: 1 瓷 8 力月, 女児.

生下時体重 $3,760 \mathrm{~g}$ にて出生, 生後 1 カ月の乳児検診 にて心雑音を指摘された。生後 3 カ月, 心ェコー検查 にてASDを疑われた。発育は良好で，生後 9 カ月まで は臨床的に何ら問題なく経過した(図 1).10カ月時の 検診にて胸部レ線上，肺血管陰影の增強を指摘され， その 1 週間後より喘鳴, 多呼吸を示すようになった。 上気道感染の診断にて投薬をらけたが症状は改善せ ず，激しい咳整，顔面および下肢に浮腫が出現し，安

昭和61年10月 1 日受付 61 年12月 9 日採用

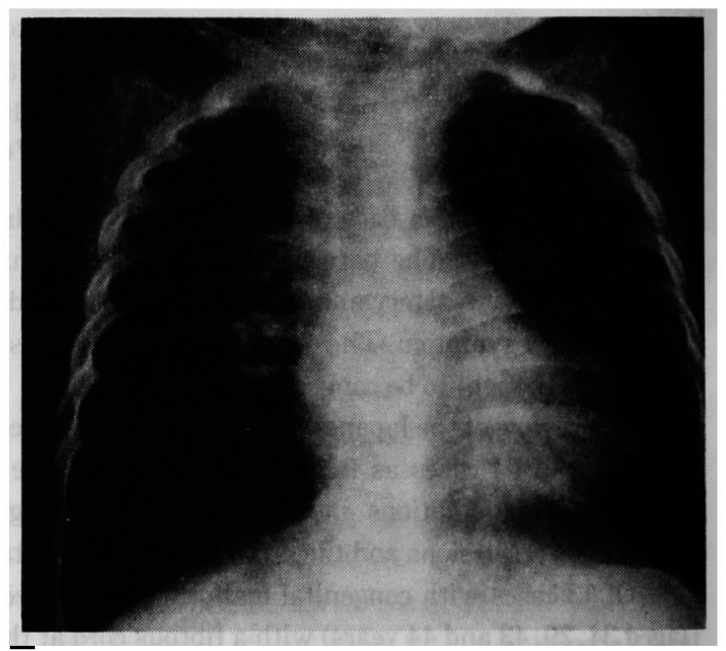

图 19 カ月時の胸部レ總渎

静時であ喘鳴が著明となり当院を紹介され入院した。

\section{入院時所見と経過}

入院時体重 $8.3 \mathrm{~kg}$, 呼吸数 $68 /$ 分, 脈拍数 $165 /$ 分, 体温 $38.3^{\circ} \mathrm{C}$, 顔面および下肢に浮腫を認め, 肺野にはラ音 が著明に聴取され，努力呼吸状態であった，心音はII 音は固定性に分裂し，胸骨左縁第 3 助間を中心に 3 度 の収縮雑音を聴取した。肝は右鎖骨中線上 $4 \mathrm{~cm}$ 触九 
た，胸部レ線（图 2）では，心胸比58\%，肺血管陰影 は增強していた，心電図は，電気軸+140度，右室肥大， 不完全右脚ブロックを示していた。 心ェュー（図3） では，右房および右室の拡大と心房中隔の欠損を認め た.

入院後，直ちにジギタリス剤および利尿剂投与を開 始したが，心不全症状は仲々改善せず，呼吸困難状態 が続き一時は気管チューブ挿入による呼吸管理を必要 とした。 入院 4 週間後ころより心不全症状は改善し呼 吸状態も良好となった。生後12力月にて心臓カテーテ ル検查 (表 1)を行ったか，肺体血流比2.5, 左 $\rightarrow$ 右短 絡66\%の ASDであった，同時に行った肺動脈造影で 肺静脈の還流は正常であった。臨床的に心不全症状は 改善し，心蔵カテーテル検査にて肺体血王比0.33と肺

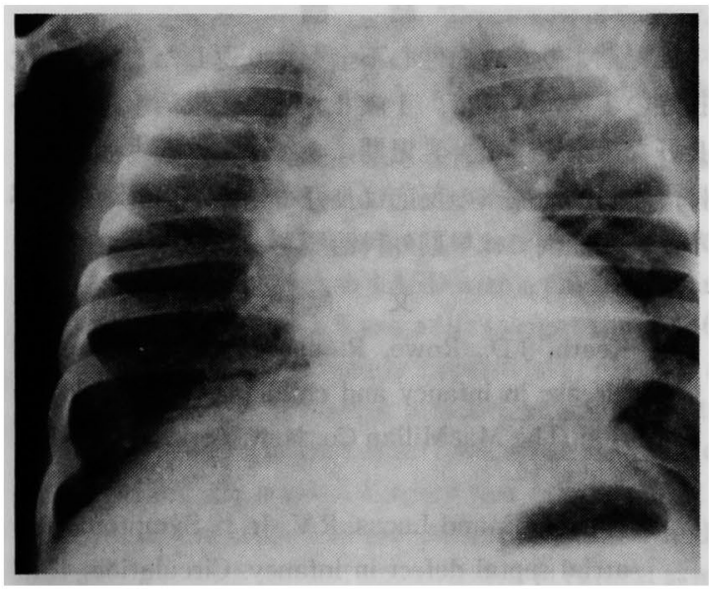

图 2 入院時（10カ月）の胸部レ緗像

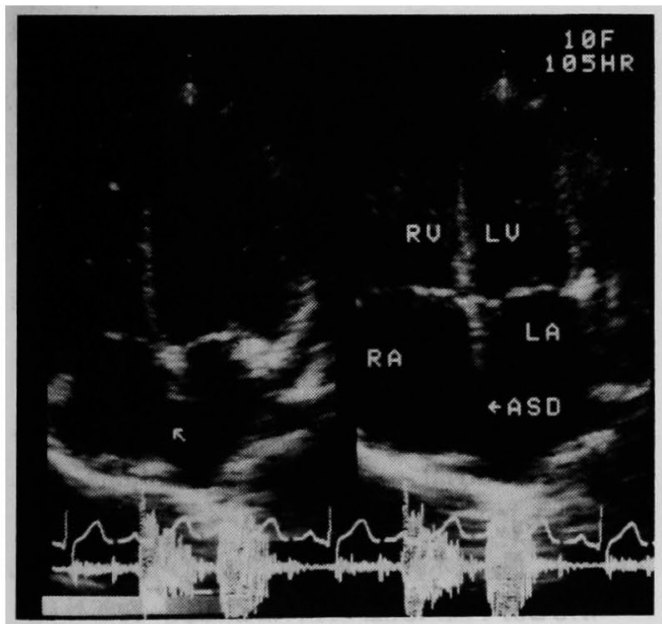

图 3 心ェコー図
表 1 心满カテーテル模查

\begin{tabular}{|c|c|c|c|}
\hline 㭘查時月龄 & \multicolumn{2}{|c|}{12 カ月 } & \multirow{2}{*}{ 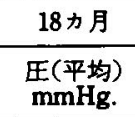 } \\
\hline 部 位 & $\begin{array}{l}\text { 压(平均) } \\
\text { mmHg. }\end{array}$ & $\begin{array}{c}\text { 酸素鹐和度 } \\
\%\end{array}$ & \\
\hline 右肺動脈 & $30 / 11(21)$ & & $38 / 11(22)$ \\
\hline 肺動脈幹 & $36 / 10(22)$ & 92 & $46 / 10(24)$ \\
\hline 右 心 室 & $51 /-1(21)$ & 93 & $60 /-1(25)$ \\
\hline 右 心 房 & $11 / 0 \quad(6)$ & 92 & $12 / 0 \quad(7)$ \\
\hline 左心房 & $17 / 0 \quad(8)$ & 99 & $17 / 0 \quad(8)$ \\
\hline 上大棦㭽 & & 76 & \\
\hline 下大静脈 & & 80 & \\
\hline 大竪動 脈 & $108 / 60$ & 98 & $100 / 58$ \\
\hline 短絡事 & 左 $\rightarrow$ & $66 \%$ & \\
\hline 肺体血流比 & & & \\
\hline
\end{tabular}

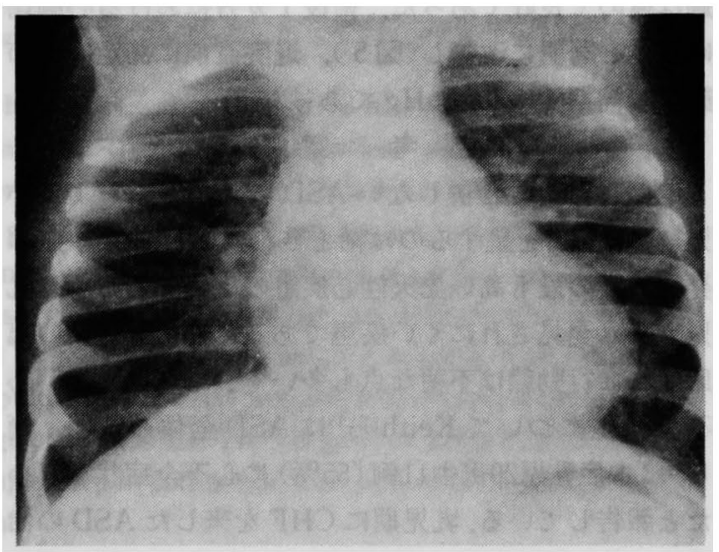

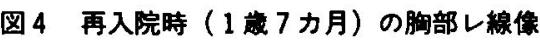

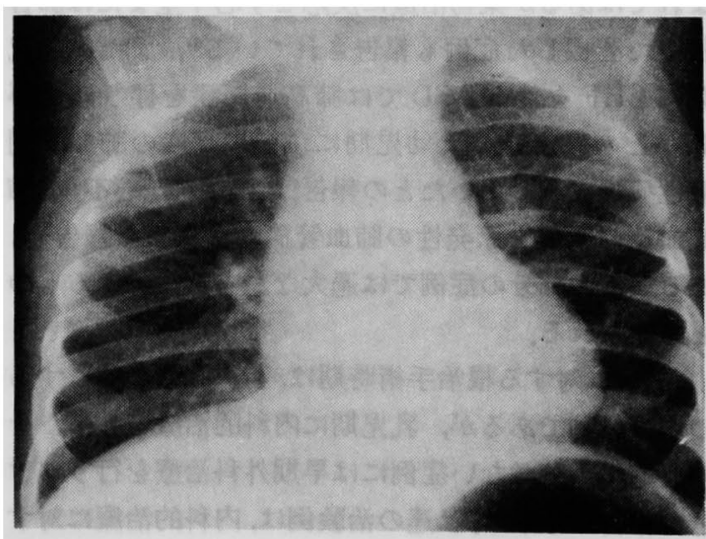

图5 術後 1 カ月時の胸部レ緗像 
高血圧症を認めなかったので経過観察可能と考えた。

強心剤を投与しながら外来にて観察を行っていた が，1歳 5 カ月頃より上気道感染が頻回となり常に喘 鳴を認めるようになった。1 歳 7 カ, 多呼吸と喘鳴 増強のため再入院した。再入院時の胸部レ線（図 4) では心胸比 $62 \%$ 之初回入院時より心拡大を示し, 肺血 管陰影む増強していた，肝は $2 \mathrm{~cm}$ 触知された。内科的 治療を行ったがその反応は十分でなく，喘鳴は消失し なかった. 再度右心カテーテル検查を行ったところ. 肺動脈圧 $46 / 10 \mathrm{mmHg}$, 右室圧 $60 /-1 \mathrm{mmHg}$, 肺体血压 比 0.43 と前回の検査時よりも内圧の上昇を認めた（表 1 ).

内科的治療の限界と考古 1 歳 8 力月に開心根治手 術を行った。手術は単純超低体温法を用いて行った。 ASD は $25 \times 15 \mathrm{~mm}$ の中心部欠損で直接繾合にて閉鎖 した. 三尖弁, 僧帽弁に異常は認めなかった. 術後経 過は極めて良好であった。術後 1 カ月における心胸比 は51\%と著明に改善し(图 5 ), 退院直前に測定した肺 動脈收縮期圧は30 mmHgであった。

\section{考案}

他の心奇形を合併しないASDで乳幼児期お゙よび小 児期に CHF を呈するのは稀とされている2/3). 本症は 発生頻度の最む高い先天性心疾患の1つであるが，乳 児期には発見されにくい疾患であるため，乳児期の臨 床像や血行動態は不明な点も多い(4)5). 本症の乳児期心 不全発生についてKeith ら ${ }^{11}$ は ASD 全体の $5 \%$, 簡 ら"は本症乳児20例中11例 (55\%) に心不全症状を認め たと報告している。乳児期にCHFを来した ASDの治 療は，強心利尿剤を中心とした内科的治療が第一選択 とされ，通常は内科的治療によく反応し，乳幼児期早 期の外科治療は必要ないとの意見が多(、2)3)5). しかし, まれではあるが薬物治療に反応せず心不全をたは肺合 併症で死亡した症例る報告されている河。 また乳幼児 期に CHF を伴う ASD では肺高血圧症を伴う頻度が 高いとの報告377》乳幼児期にすでに高度の肺血管閉 塞性病変を来していたとの報告48899 するる.心不全, 肺 高血正の原因を原発性の肺血管病変に求めた報告9 。 あるが，大部分の症例では過大な左右短絡によるもの と考えられる。

ASD に対する根治手術時期は, 4 ～歳に施行する のが一般的であるが，乳児期に内科的治療を要し，そ の反応が十分でない症例には早期外科治療を行うべき との報告 ${ }^{10)}$ ある.私達の治験例は，内科的治療に対す る反応が十分でなかった事拉よび二度目の右心カテー
テル検查にて肺動脈，右心室收縮期匠の上䄯を認めた ので早期外科治療を行った。本症の乳児期重症例に対 する手術時期について, 門間ら゙住 1 2 嵅で心缄力 テーテル検查を反復して行い, 決めるべきであるとし ている.ASD 閉鎖時期の遅れのため手術死亡や不可逆 性の肺血管病変で遠隔死亡したとの報告"1)あり，乳 児期に心不全を合併した ASD では早期外科治療を考 庵すべき症例もある.ASD の乳児期手術成績は不良と の報告23があるが，近年の乳児期開心術の手術成績は 飛羅的に向上しておう，ASDでむ良好な成績が報 告?111 13)されている. 私達の症例でる術中, 術後の血行 動態は良好で，退院後の経過すなんら内科的治療を必 要とせず元気に発育している，内科的治療に十分反応 しないASDでは，乳児期であっても積極的に外科治 療を行らべきと考之る。

\section{結 論}

乳児期よりうっ血性心不全をくり返した心房中隔欠 損症の 1 例に対して，1歳 8 カ月にて根治手術を行い 良好な結果を得た。乳児期に心不全を伴ら本症の多く は，内科的治療への反応は良好であるが，その反応が 不十分な症例では早期外科治療を考虑すべきである。

\section{文献}

1) Keath, J.D., Rowe, R. and Vlad, P.: Heart disease in infancy and childhood. Second Edition, The MacMillan Co. New York, 1967, p392 -431 .

2) Hunt, C.E. and Lucas, R.V. Jr.: Symptomatic atrial septal defect in infancy. Circulation, 47 : 1042-1048, 1973.

3) Phillips, S.J., Okies, J.E., Henken, D., et al. : Complex of secundum atrial septal defect and congestive heart failure in infancy. J. THorac. Cardiovasc. Surg., 70 : 696-700, 1975.

4）簡 瑞祥, 浜田朗生, 河村研一他：乳児期に括ける 心房中隔欠損症の臨床像, 日児誌, $84: 625-629$, 1980.

5）多田罹勝義, 藤けい子, 田原佳子他：乳児期に発 見された二次孔型心房中隔欠損症，小児臨，37： 1003-1007, 1984.

6) Dimich, I., Steinfeld, L. and Park, S.C.: Symptomatic atrial septal defect in infants. Am. Heart J., 85 : 601-604, 1973.

7) 横山 温, 荒木純一，佐藤成和他：心不全を伴 5 乳 幼览心房中隔欠損症の外科治療経臨、胸部外科, 34 : 959-962, 1981. 
8）門間和夫, 高尾第良, 安藤正彦他：高度の肺高血圧 を伴 5小児の心房中隔欠損症，心珹，6:1870 $-1876,1974$.

9）野中善治，河村研一，坂戸信行他：乳児期より高度 の肺高血圧症を呈して死亡した心屏中久損症の 1 例，小児臨，33：1429-1432，1980。

10) Spanger, J.G., Feldr, R.H. and Danielson, G.K. : Secundum atrial septal defect encounted in infancy. J. Thorac. Cardiovasc. Sury., $71: 398$ $-401,1976$.
11) Bull, C., Deanfield, J., DeLeval, M., et al.: Correction of isolated secundum atrial septal defect in incancy. Arch. Dis. Child., 56: 784 $-786,1981$.

12）東 茂樹，木曾一誠，林 郁夫他：乳幼児期に心不 全を呈した心房中隔欠損症の 2 例，小児外科，15： 253-257, 1983.

13）大北 裕, 三木成仁，楠原健司她：乳児期に5っ血 性不全を呈した心房中隔欠損症の 2 治稌例，日胸 外会誌, $34: 892-896,1986$.

\title{
A CASE OF SECUNDUM ATRIAL SEPTAL DEFECT WITH CONGESTIVE HEART FAILURE IN EARLY CHILDHOOD
}

\author{
Yuichiro OIKAWA, Hideo MURAI*, Ippei YASUDA** and Takae KAWAMURA*** \\ Department of Cardiovascular Surgery, Hakodate Goryokaku Hospital \\ *Department of Surgery, Hakodate Goryokaku hospital \\ **Department of Pediatrics, Hakodate Goryokaku Hospital \\ ***:Department of Anesthesia, Iwate Medical University
}

We treated a patient with atrial septal defect (ASD) who had repeated congestive heart failure starting in infancy, but showed symptomatic improvement by early surgical treatment. The patient was a 20-month-old female. At the age of 10 months, she was hospitalized for severe cardiac insufficiency. Detailed cardiac examination at 12 months of age revealed ASD with a pulmonary arterial pressure of $36 / 10(22) \mathrm{mmHg}$, a ratio of pulmonary to systemic flow rates of 2.5 and a left-to-right shunt of $66 \%$. Improvement in the symptoms of cardiac insufficiency and the absence of pulmonary hypertension justified a non-surgical follow-up. At the age of 19 months, she was again admitted with cardiac insufficiency and was treated by medical therapy without success. Since cardiac catheterization performed again detected an elevation of the pulmonary arterial pressure from the previous level to $46 / 10$ (24) $\mathrm{mmHg}$, radical surgery was carried out at the age of 20 months. The surgical procedure consisted of direct suture of a $25 \times 15 \mathrm{~mm}$ ASD in the center under simple deep-hypothermia. The postoperative course was satisfactory, with marked improvement in clinical symptoms. 